Article

\title{
Spatial and Temporal Variations in Crustal Structure in the Eurasian Basin
}

\author{
Lihong Zhao ${ }^{1}$, Tao Zhang ${ }^{2,3} \mathbb{D}$, Zilong Ling ${ }^{1,2,3,4, *}$, Mujie Li ${ }^{1}$, Pengyao Zhi ${ }^{1}$, Renwei Ding ${ }^{1} \mathbb{D}$ and Chaoyang Li ${ }^{1}$ \\ 1 College of Earth Science and Engineering, Shandong University of Science and Technology, \\ Qingdao 266590, China; zhaolihong@sdust.edu.cn (L.Z.); 1mj980919@163.com (M.L.); \\ skd993971@sdust.edu.cn (P.Z.); rwding@sdust.edu.cn (R.D.); lichaoyang@sdust.edu.cn (C.L.) \\ 2 Key Laboratory of Submarine Geosciences, Ministry of Nature Resources, Hangzhou 310012, China; \\ tao_zhang@sio.org.cn \\ 3 Second Institute of Oceanography, Ministry of Nature Resources, Hangzhou 310012, China \\ 4 Laboratory for Marine Mineral Resources, Pilot National Laboratory for Marine Science and Technology, \\ Qingdao 266237, China \\ * Correspondence: lz1137607@163.com
}

Citation: Zhao, L.; Zhang, T.; Ling, Z.; Li, M.; Zhi, P.; Ding, R.; Li, C. Spatial and Temporal Variations in Crustal Structure in the Eurasian Basin. J. Mar. Sci. Eng. 2022, 10, 157. https:// doi.org/10.3390/jmse10020157

Academic Editor: János Kovács

Received: 28 December 2021

Accepted: 20 January 2022

Published: 26 January 2022

Publisher's Note: MDPI stays neutral with regard to jurisdictional claims in published maps and institutional affiliations.

Copyright: (C) 2022 by the authors. Licensee MDPI, Basel, Switzerland. This article is an open access article distributed under the terms and conditions of the Creative Commons Attribution (CC BY) license (https:// creativecommons.org/licenses/by/ $4.0 /)$.

\begin{abstract}
To understand the tectonic-magmatic history, crustal structure and crustal accretion mode of the Eurasian Basin in the Arctic, we calculated the crustal thickness, residual bathymetry (RB) and non-isostatic topography of the Eurasian Basin by using the latest bathymetry, free-air gravity anomaly, crustal age and sediment thickness data. The tectonic-magmatic process of the Eurasian Basin can be divided into two stages. During magnetic isochrons 24-13 (C24-C13), the crustal structure of the basin was characterized by regional variations, while the crustal structure of the basin was characterized by local variations during magnetic isochrons 13-0 (C13-0). On the whole, the western part of the basin had a thicker crustal thickness and higher RB than the eastern part of the basin during C24-C13, which should result from the northward movement of Greenland. During magnetic isochrons 24-20 (C24-C20), the crustal structure of the eastern part of the basin had abnormally strong asymmetry. We speculate that there may be mantle upwelling beneath the Kara Sea Shelf in the south of the Eastern Eurasian Basin, which provides a large amount of melt for the crustal accretion of the southern part of the Eastern Eurasian Basin. The melt focusing supply could generate abnormally thick crust $(>7 \mathrm{~km}$ ) during magma enhancement period. The Western Eurasian Basin had stronger spatial variability and more frequency asymmetric polarity reversal than the Eastern Eurasian Basin during magnetic isochrons 6-0 (C6-0). We attribute this to the inflow of the North Atlantic mantle.
\end{abstract}

Keywords: Eurasian basin; crustal thickness; tectonic-magmatic history; crustal accretion; asymmetry

\section{Introduction}

In recent years, the global warming and potential natural resources led to the interest for studying the Arctic exponentially increase. As the youngest tectonic province in the Arctic Ocean, the Eurasian Basin is the key to study the Arctic region. However, the harsh climate environment, remote location and sparse geophysical and geological data limit our understanding of the crustal structure and tectonic-magmatic process of the Eurasian Basin. Although some studies on the crustal structure have been conducted, they mostly focused on the Gakkel Ridge and the western part of the Eurasian Basin [1-4]. In addition, the Gakkel Ridge forming the Eurasian Basin is the ultra-slow spreading ridge (it has the slowest spreading rate in the world) that has a unique crustal accretion model and lithospheric characteristics; it is an ideal region to study the magmatic and tectonic behavior of the spreading ridges [2]. Therefore, the study of the crustal thickness of the Eurasian Basin can not only improve our understanding of the formation process of the Eurasian Basin, but also help us to understand the crustal accretion mechanism of the ultra-slow spreading ridge. 
The seismic study of the crustal thickness of the Eurasian Basin is scarce. Jokat and Schmidt-Aursch [5] reported on the crustal thickness of the Gakkel Ridge by analyzing 13 seismic stations deployed on ice floes in the central valley. They found that the oceanic crustal thickness was up to $4.9 \mathrm{~km}$ beneath some of centers of focused magmatism, and the crust thinned to $1.4-2.9 \mathrm{~km}$ in amagmatic segments. Urlaub et al. [6] computed the 2-D crustal structure model for the Nansen and Amundsen basins by using shipborne gravity profile and seismic data. They found that the crustal thickness was mainly less than $1 \mathrm{~km}$ in the oldest parts of both basins but could reach $6 \mathrm{~km}$ near the Gakkel Ridge. Schmidt-Aursch and Jokat [4] obtained a 3-D gravity model of the crustal thickness over the Gakkel Ridge and parts of adjacent region west of $65^{\circ} \mathrm{E}$ by using the forward modeling method. Their results showed that the Eurasian Basin had a thin crust $(1-3 \mathrm{~km})$ prior to magnetic isochrons 5/6 (C5/C6). Some scholars have obtained the crustal thickness model of the whole Arctic region by using gravity inversion [7-9]. However, the inversion parameters cannot fully conform to the characteristics of the crustal structure of the Eurasian Basin due to the fact that the Arctic contains a variety of tectonic provinces, resulting in a large deviation in the crustal thickness results of the Eurasian Basin.

We use the latest bathymetry, free-air gravity anomaly, sediment thickness and crustal age data to compute the crustal thickness of the Eurasian Basin with seismic constrains. To study the tectonic-magmatic history of the Eurasian Basin and the crustal accretion mechanism of the Gakkel Ridge, we also calculated the residual bathymetry and non-isostatic topography, and we quantified their temporal and spatial variations and asymmetry.

\section{Geological Setting}

The Eurasian Basin formed about 56 Ma ago and is composed of the Nansen Basin, the Amundsen Basin, and the Gakkel Ridge (Figure 1a) [10,11]. The basin is connected to the North Atlantic Ocean via the Fram Strait between Svalbard and Greenland, and it is bounded by the Laptev Sea Shelf on the west. According to magnetic data, Glebovsky et al. [11] found that at the initial stage of the basin opening in the early-middle Eocene approximately 53-44 Ma ago (magnetic isochrons 24-20, C24-C20), it had a relatively high spreading rate, with a total spreading rate of $22-27 \mathrm{~mm} /$ year. Subsequently, the spreading rate sharply decreased to a minimal value of $5-9 \mathrm{~mm} /$ year in the Oligocene-early Miocene (magnetic isochrons 13-6, C13-C6). At present, the Gakkel Ridge is the mid-ocean ridge with the slowest spreading rate in the world. The spreading rate gradually decreases from $\sim 12 \mathrm{~mm} /$ year in the west to $\sim 6 \mathrm{~mm} /$ year in the east [1,4].

Along the axis of the Gakkel Ridge, amagmatic segments without any igneous crust alternate with magmatic segments with large volcanoes $[1,4]$. The western part of the Gakkel Ridge (west of $85^{\circ} \mathrm{E}$ ) is divided into three tectonic-magmatic zones based on magnetic, bathymetry, and rock sampling data [1], as follows: the Western Volcanic Zone (WVZ, $\left.6^{\circ} 30^{\prime} \mathrm{W}-3^{\circ} 30^{\prime} \mathrm{E}\right)$, the Sparsely Magmatic Zone (SMZ, $\left.3^{\circ} 30^{\prime} \mathrm{E}-29^{\circ} \mathrm{E}\right)$, and the Eastern Volcanic Zone (EVZ, $\left.29^{\circ} \mathrm{E}-85^{\circ} \mathrm{E}\right)$. The WVZ has strong magmatism and high magnetic anomaly. Rocks recovered in the WVZ are virtually all basalts. The SMZ has weak magmatic activity. The mantle peridotites are exposed on the seafloor in the SMZ. The EVZ is composed of six volcanic centers. Near a volcanic center, magmatic activity is strong, and basalts predominate the recovered rocks. However, between volcanic centers, the magmatic activity is weak and rock samples are mainly peridotite. In addition, six off-axis basement ridges (Figure $1 \mathrm{a})-\mathrm{A}\left(10^{\circ} \mathrm{E}\right), \mathrm{B}\left(19^{\circ} \mathrm{E}\right), \mathrm{C}\left(31^{\circ} \mathrm{E}\right), \mathrm{D}\left(42^{\circ} \mathrm{E}\right), \mathrm{E}\left(62^{\circ} \mathrm{E}\right)$, and $\mathrm{F}\left(70^{\circ} \mathrm{E}\right)$ - occur in the western part of the Gakke Ridge; they are considered to be unique crustal feature of the ultra-slow spreading ridge [1]. 

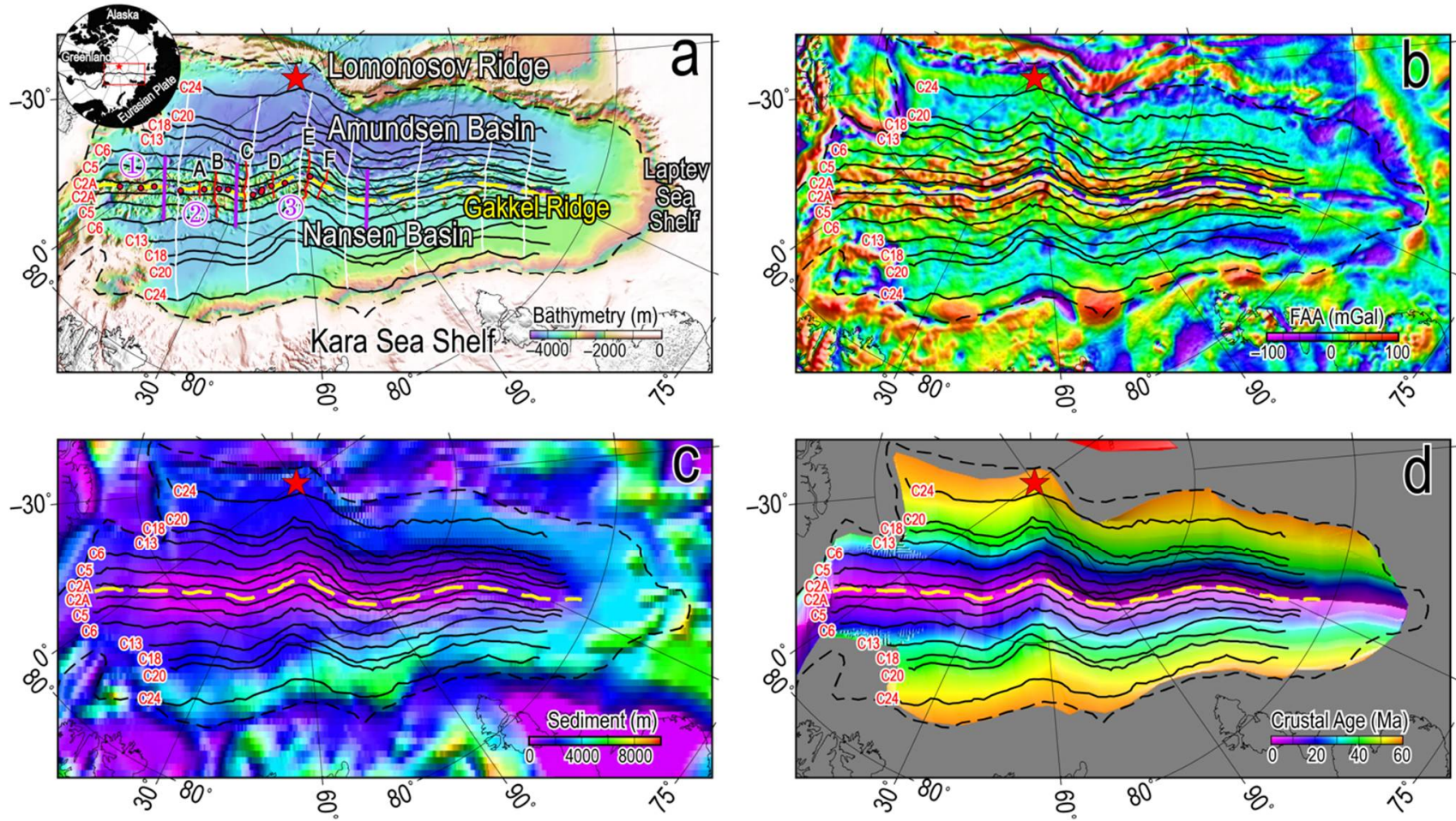

Figure 1. (a) Bathymetry of the Eurasian Basin. Red five-pointed star indicates the North Pole. Black lines indicate the magnetic isochrones of the Eurasian Basin. Black dotted line indicates the ocean-continent boundary. (1) indicates the WVZ. (2) indicates the SMZ. (3) indicates the EVZ. White line indicates the flowline of Gakkel Ridge. Red lines indicate the basement ridges. Yellow dotted line indicates the spreading axis. (b) Free-air gravity anomaly. (c) Sediment thickness. (d) Crustal age.

The plate reconstruction model suggests that the Eurasian Basin formation should precede the opening of the Greenland-Norway Sea and should be connected to the Labrador Sea via Baffin Bay [10,12]. During the late Cretaceous-late Eocene (ca. 70-35 Ma), Greenland continued to move northward relative to the North American and Eurasian plates, eventually resulting in Greenland joining the North American plate and the separation of the Yermak Plateau and the Morris Jesup Rise $[4,10,11]$. This caused the formation of the WVZ and the connection of the Eurasian Basin with North Atlantic Ocean.

In addition, the crust structure of the Eurasian Basin has obvious asymmetry. The basement of the Amundsen Basin is more rugged and shallower than that of the Nansen Basin $[13,14]$. Based on the analysis of the subsidence and spreading rate of the basement, it is considered that this may be the result of the asymmetric spreading rate [13]. Vogt et al. [15] was the first to observe the asymmetry of the spreading rate: at 20-0 Ma, the spreading rate of the Amundsen Basin was 10-20\% slower than that of the Nansen Basin, and the asymmetry became more and more obvious as the crustal age increased. Glebovsky et al. [11] found that in the basin opening before the C24, the crust increment of the Amundsen Basin was about $40 \mathrm{~km}$ more than that of the Nansen Basin. Ling et al. [16] found that the crustal structure of basement ridges $C$ and $E$ have asymmetric crustal structure.

\section{Data and Method}

\subsection{Input Data}

Topography and bathymetry grid data (Figure 1a) were obtained from International Bathymetry Chart of the Arctic Ocean Version 4.0 (IBCAO Ver. 4.0) [17] with a grid spacing of $200 \mathrm{~m} \times 200 \mathrm{~m}$. IBCAO Ver. 4.0 incorporates new shipborne data and constrains $\sim 19.8 \%$ of the area of the Arctic Ocean with individual depth soundings. Modern multibeam bathymetry occupies $\sim 14.3 \%$ of the area of the Arctic Ocean. 
Free-air gravity anomaly data (Figure $1 b$ ) were derived from the DTU21 global gravity model at $1^{\prime} \times 1^{\prime}$ from the Danish Technical University [18]. DTU21 contains new measurement data from two polar orbiting satellite radar altimeters (Cryosat-2 and SARAL/AltiKa).

Sediment data (Figure 1c) were extracted from the ArcCRUST sediment grid data with a grid spacing of $10 \mathrm{~km} \times 10 \mathrm{~km}$ [9]. ArcCRUST sediment grid data incorporates the latest sediment data of the Arctic Ocean.

Crustal age data (Figure 1d) were extracted from the latest global ocean crustal age data model with a grid spacing of $1^{\prime} \times 1^{\prime}$ [19]; this model is based on the magnetic anomaly identifications and plate tectonics model of Müller et al. [20].

\subsection{Mantle Bouguer Anomaly}

We used the FA2BOUG program [21] to convert free-air gravity anomaly to Bouguer gravity anomaly with the topography data from IBCAO Ver. 4.0 grid for terrain corrections. In order to remove the gravity effect caused by sediment, we used the method of Rao and Babu [22] to calculate the gravity anomaly of sediments at the sea level (Figure 2a). Since sediment density increases with depth, we calculated gravity anomaly using the densitydepth function of Lebedeva-Ivabova et al. [9]. The complete Bouguer gravity anomaly was obtained by removing the gravity effects of the sediment from the Bouguer gravity anomaly. Further, we removed the gravity effects of the crust-mantle density interface from the complete Bouguer gravity anomaly to obtain the mantle Bouguer gravity anomaly (MBA). Based on the seismic crustal thickness, the uniform crustal thickness was assumed to be $3 \mathrm{~km}$. The densities of sea water, basement rock, crust, and mantle are 1030, 2670, 2800 and $3300 \mathrm{~kg} / \mathrm{m}^{3}$, respectively.

\subsection{Thermal Correction}

We used the simple 1-D plate cooling model [23] and the 2-D crustal age grid to calculate the 3-D mantle thermal model for a $100 \mathrm{~km}$ thick layer. The temperature was set to be $T_{0}=0{ }^{\circ} \mathrm{C}$ at the surface and $T_{m}=1350{ }^{\circ} \mathrm{C}$ at $100 \mathrm{~km}$ depth. The 3-D mantle thermal model was converted into a 3-D density structure using the thermal expansion equation, $\Delta \rho=T_{0}-\mathrm{T} \alpha \rho_{0}$, where $T_{0}, \rho_{0}$ and $\alpha$ are the reference temperature, reference density, and thermal expansion coefficient, respectively. In the calculation, these parameters were set to $T_{0}=1350{ }^{\circ} \mathrm{C}, \rho_{0}=3300 \mathrm{~kg} / \mathrm{m}^{3}$, and $\alpha=3.5 \times 10^{-5}{ }^{\circ} \mathrm{C}^{-1}$. Thus, we could obtain the gravity effects of lithospheric cooling (Figure $2 b$ ).

\subsection{Residual Mantle Bouguer Anomaly and Crustal Thickness}

The Residual Mantle Bouguer Anomaly (RMBA, Figure 2c) was calculated by removing the thermal correction from the MBA. The RMBA reflects the deviation from the assumed crustal-mantle structure in a calculation, which is caused by the combined effects of crustal thickness, crustal density, and mantle temperature [16,24]. It is possible to obtain the maximum relative crustal thickness variations if assuming that the RMBA signal is only caused by crustal thickness variations. Here, the crustal thickness was calculated via the downward continuation of the RMBA to a constant depth using the method of Parker [25]. The downward continuation depth was set to be $7 \mathrm{~km}$, i.e., the sum of the average water depth $(4 \mathrm{~km})$ and the average crustal thickness $(3 \mathrm{~km})$. The RMBA data was filtered using a cosine taper before downward continuation. There is a trade-off between the crust thickness and the crust-mantle density difference [26]. For the same RMBA, a larger crustal-mantle density difference will produce a smaller lateral crustal thickness variation [26]. In order to obtain the best crustal thickness model, we fixed the mantle density at $3300 \mathrm{~kg} / \mathrm{m}^{3}$, assuming that the crustal thickness varies between $2700 \mathrm{~kg} / \mathrm{m}^{3}$ and $2900 \mathrm{~kg} / \mathrm{m}^{3}$ in steps of $500 \mathrm{~kg} / \mathrm{m}^{3}$, and we calculated a series of corresponding crustal thickness models. Then, we compared these crustal thickness models with the crustal thickness determined by 13 seismic stations [5] and calculated the best fitting slope and RMS for difference between gravity-derived and seismically determined crustal thickness (Table 1). We found that the crustal thickness model with a crustal density of $2800 \mathrm{~kg} / \mathrm{m}^{3}$ 
had both the smallest RMS and best fitting slope close to 1 . Therefore, the crustal thickness model with a crust/mantle density contrast of $500 \mathrm{~kg} / \mathrm{m}^{3}$ was considered to be the best crustal thickness model (Figure 3a).
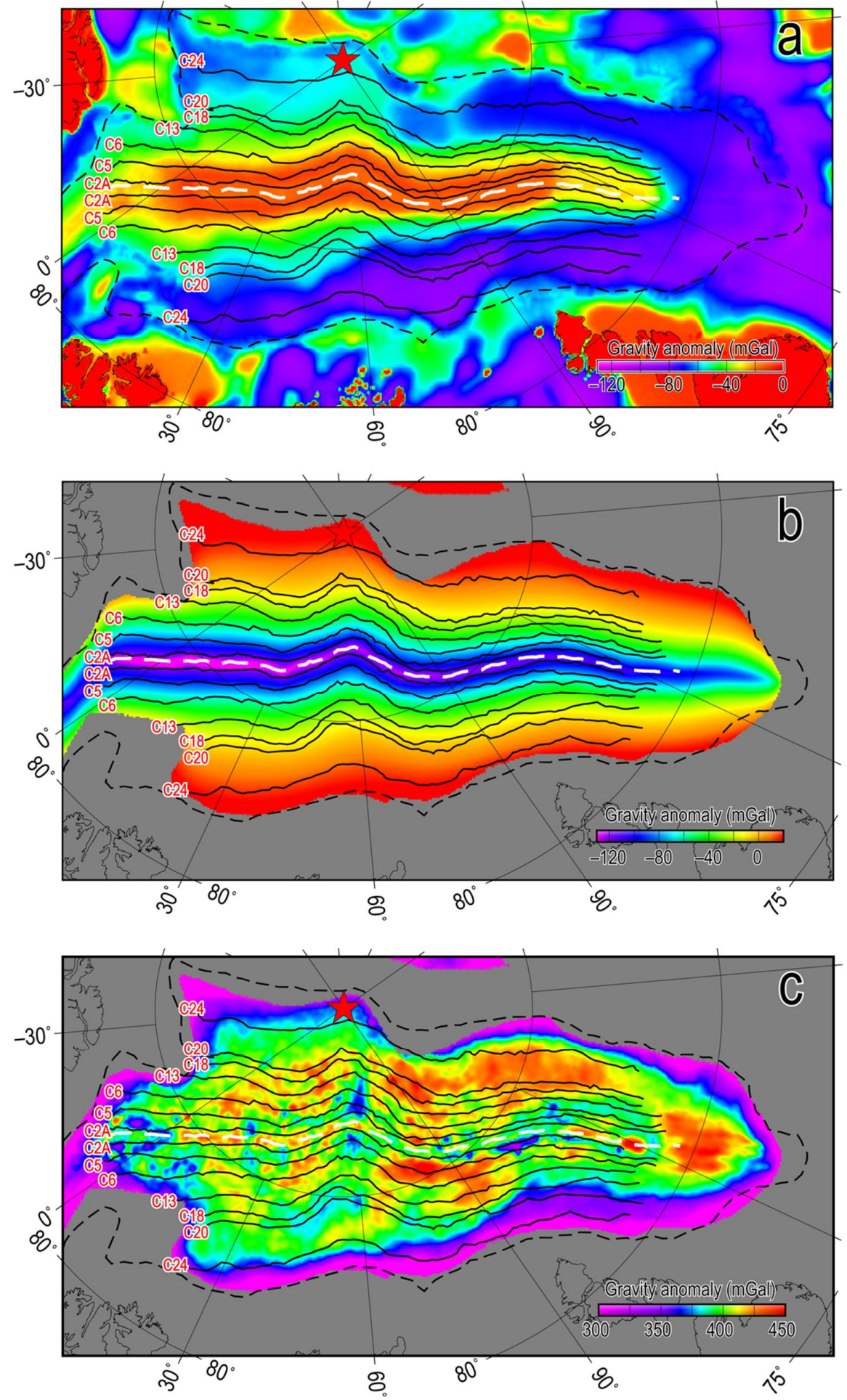

Figure 2. (a) Map of calculated gravity effects of sediment. Red five-pointed star indicates the North Pole. Black lines indicate the magnetic isochrones of the Eurasian Basin. Black dotted line indicates the ocean-continent boundary. White dotted line indicates the spreading axis. (b) Map of calculated gravity effects of thermal correction. (c) Map of calculated residual mantle bouguer anomaly. 
Table 1. Sensitivity of model results to assumed crustal density.

\begin{tabular}{ccc}
\hline Assumed Crustal Density $\left(\mathbf{k g ~ m}^{-\mathbf{3}}\right)$ & Best Fitting Slope $^{\mathbf{a}}$ & RMS $_{\mathbf{~ ( k m})} \mathbf{b}^{\mathbf{b}}$ \\
\hline 2.7 & 0.69 & 0.68 \\
2.75 & 0.63 & 0.71 \\
2.8 & 0.72 & 0.65 \\
2.85 & 0.58 & 0.74 \\
2.9 & 1.7 & 0.72
\end{tabular}

a Fit of the data using the relationship: seismic thickness $C_{\text {seis }}=C_{i}+R \times C_{g r a}$, where $C_{i}$ is the y intercept, $R$ is the best fitting slope, and $C_{g r a}$ is the gravity-derived thickness. ${ }^{b}$ Root mean square for the difference between gravity-derived and seismic crustal thickness.
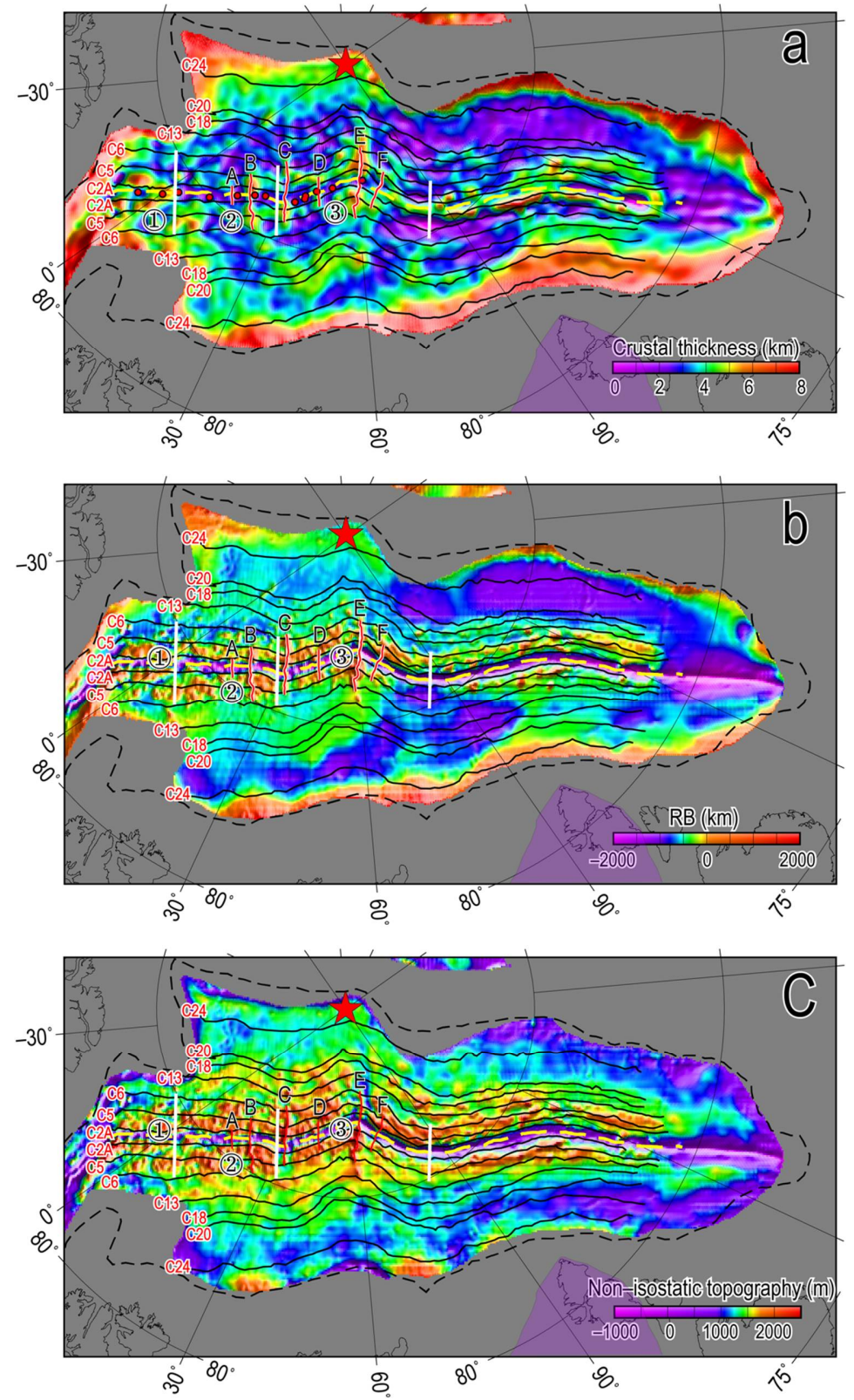

Figure 3. (a) Map of crustal thickness. Black lines indicate the magnetic isochrones of the Eurasian Basin. Black dotted line indicates the ocean-continent boundary. (1) indicates the WVZ. (2) indicates the SMZ. (3) indicates the EVZ. White line indicates the flowline of Gakkel Ridge. Red lines indicate the basement ridges. Yellow dotted line indicates the spreading axis. Purple shadow indicates the high magnetic anomaly zone. (b) Map of residual bathymetry. (c) Map of non-isostatic topography. 
We compared the gravity-derived crustal thickness values with 13 seismically determined crustal thickness values in the central valley in order to evaluate the robustness of the crustal thickness model. Figure 4 show the relationship between gravity-derived and seismically determined crustal thickness. The gravity-derived results agreed relatively well with the seismic results. The average and standard deviation for the difference between gravity-derived and seismically determined crustal thickness were $0.05 \mathrm{~km}$ and $0.81 \mathrm{~km}$, respectively.

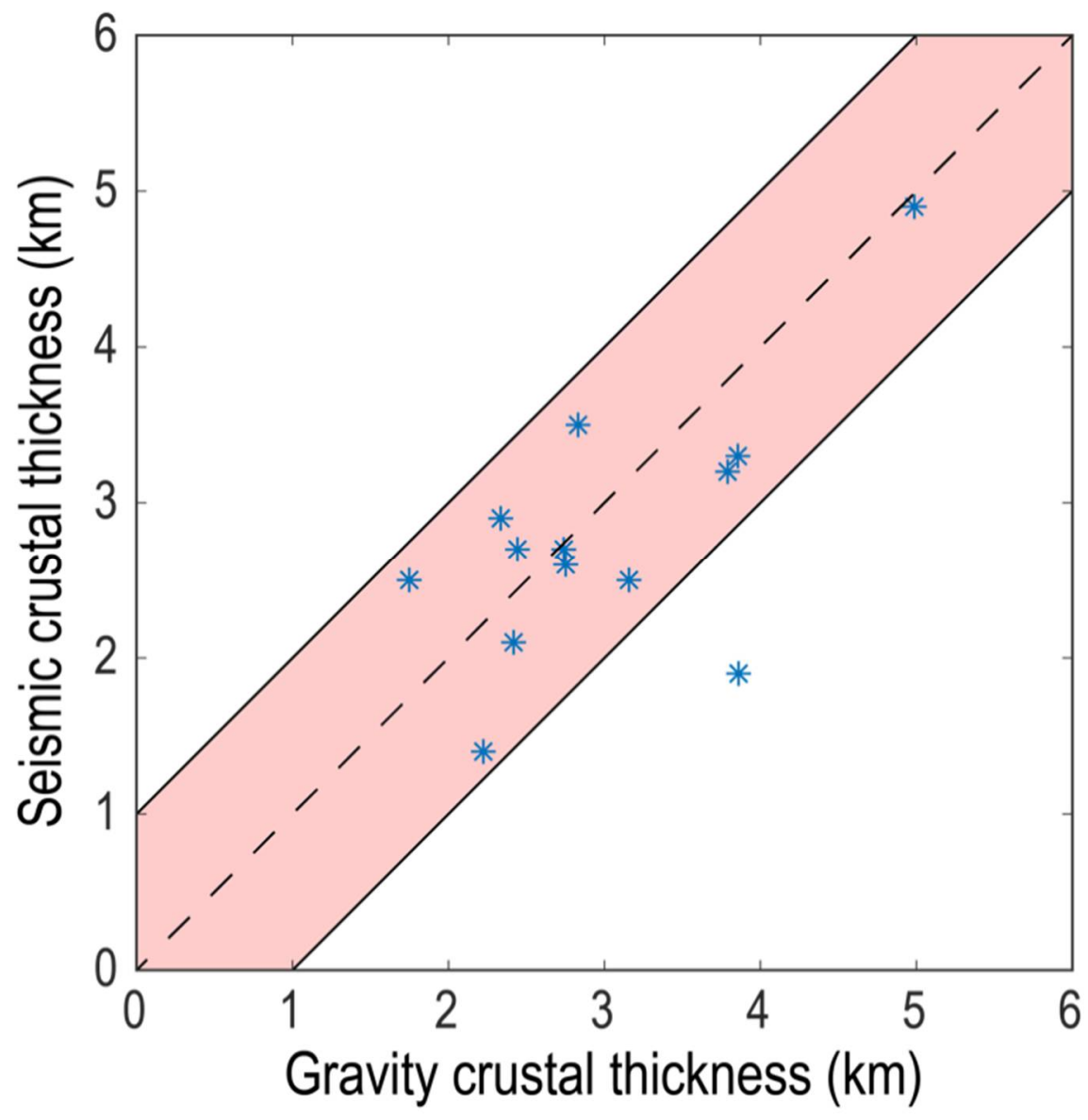

Figure 4. Comparison of gravity-derived crustal thickness values with seismically determined crustal thickness values from 13 seismic stations.

\subsection{Residual Bathymetry}

The residual bathymetry (RB, Figure $3 b$ ) was obtained by removing the thermal subsidence of lithospheric cooling and sediment loading from the observed seafloor bathymetry. $\mathrm{RB}$ reflects the initial topography of mid-ocean ridge formation and later off-axis tectonicmagmatic activity. The sediment loading correction was calculated assuming Airy compensation: $\Delta Z=h_{s}\left(\rho_{m}-\rho_{s}\right) /\left(\rho_{m}-\rho_{w}\right)$, where $\Delta Z$ is the correction value; $h_{s}$ is the sediment thickness; and $\rho_{m}, \rho_{w}$, and $\rho_{s}$ are the mantle density, sea water density, and sediment density, respectively. The values are the same as those in the calculation of the MBA. The thermal subsidence caused by lithospheric cooling was calculated using the plate cooling model of Stein and Stein [27].

$$
\begin{gathered}
D=2600+365 t^{\frac{1}{2}}, t<20 M a \\
D=5651-2473 \exp (-0.0278 t), t>=20 M a
\end{gathered}
$$

where $\mathrm{D}$ and $\mathrm{t}$ are the thermal subsidence value and the crustal age, respectively. 


\subsection{Non-Isostatic Topography}

Furthermore, we obtained the non-isostatic topography by subtracting the isostatically compensated topography from the RB. Non-isostatic topography (Figure 3c) reflects the topographic features that are supported by lithospheric stress. A high non-isostatic topography value indicates relatively insufficient deep compensation and a topography supported by tectonic stress, while low non-isostatic topography value indicates that the lithosphere is in a state of relatively isostatically compensation.

$$
\Delta h_{i s o}=\Delta h \times\left(\rho_{m}-\rho_{c}\right) /\left(\rho_{m}-\rho_{w}\right)
$$

where, $\Delta h_{\text {iso }}$ and $\Delta h$ are isostatic topography and the crustal thickness, respectively, and $\rho_{m}, \rho_{c}$, and $\rho_{w}$ are the mantle density, crustal density, and sea water density, respectively, as noted in the calculation of the MBA.

\section{Results}

We used polar stereoscopic projection to project all data onto Cartesian coordinates to eliminate the errors caused by the planar treatment of curvilinear coordinates. We resampled all the data onto $5 \mathrm{~km}$ grids. In addition, in order to eliminate the boundary effect, we mirrored the data before data processing. A large number of observations and simulations have shown that in a slow spreading mid-ocean ridge, magmatic segments and amagmatic segments occur alternately, which significantly affects the crustal structure and topography [28-30]. In order to quantitatively analyze the spatial and temporal variations of crustal structure and tectonic-magmatic activity in the Eurasian Basin, we calculated the variations of crustal thickness, residual bathymetry and non-isostatic topography at different stages of the basin's evolution (Figure $5 \mathrm{a}-\mathrm{c}$ ) according to the magnetic isochrone and flowline. We generated flowlines along the ridge from the west to the east at an interval of $20 \mathrm{~km}$, sampled the data along the flowline, and projected the data onto the ridge axis. We averaged all data with same crustal age and used them as the crustal structure feature at the stage of the basin' evolution. In addition, we obtained asymmetry using the data of the north of the ridge (Amundsen Basin) minus the data with same crustal age on the conjugate side (Nansen Basin) (Figure 5d-f).

\subsection{Crustal Thickness}

The crustal thickness of the Eurasian Basin was found to range from $0 \mathrm{~km}$ to $9 \mathrm{~km}$. In the initial spreading stage (C24-C20, 53-44 Ma), although the Eurasian Basin had the thickest crustal thickness $(4.3 \pm 0.53 \mathrm{~km})$, it was much thinner than the normal oceanic crustal thickness $(6-8 \mathrm{~km})$, indicating that the melting was weak and the magma supply was small during basin formation. During C20-C18 (44-40 Ma), the crustal thickness of the basin significantly decreased to about $3.65 \mathrm{~km}$. Subsequently, the average crustal thickness of the basin did not significantly change.

During C24-C6 (53-20 Ma), the spatial variability of crust thickness was relatively weak, and the standard deviation was less than $0.5 \mathrm{~km}$. In contrast, during C6-0 (20-0 Ma), the crustal thickness of the basin had a strong spatial variability (STD $>0.7 \mathrm{~km}$ ). The local thickening of the crust and the appearance of basement ridge reflected the melt focusing supply of the Gakkel Ridge. During C5-C2A (11-3.5 Ma), the overall crust of the basin was significantly thickened, and the average crustal thickness increased to $\sim 3.9 \mathrm{~km}$. The WVZ had a relatively thick crustal thickness $(>4 \mathrm{~km})$, indicating that the magma supply was relatively strong. In the SMZ and the EVZ, the crustal thickness was obviously thinner than that in the WVZ, but the crust near the basement ridge was significantly thickened, indicating that the magmatism was mainly concentrated on the basement ridge. During C5-C2A, there are three obvious crustal thickening zones $\left(91^{\circ} \mathrm{E}, 97^{\circ} \mathrm{E}\right.$ and $108^{\circ} \mathrm{E}: \mathrm{G}, \mathrm{H}, \mathrm{I}$, respectively, in Figure 5) in the eastern part of the basin. Compared to the surroundings, their crust was thickened by $\sim 2 \mathrm{~km}, \sim 2.4 \mathrm{~km}$ and $\sim 3 \mathrm{~km}$, respectively. 

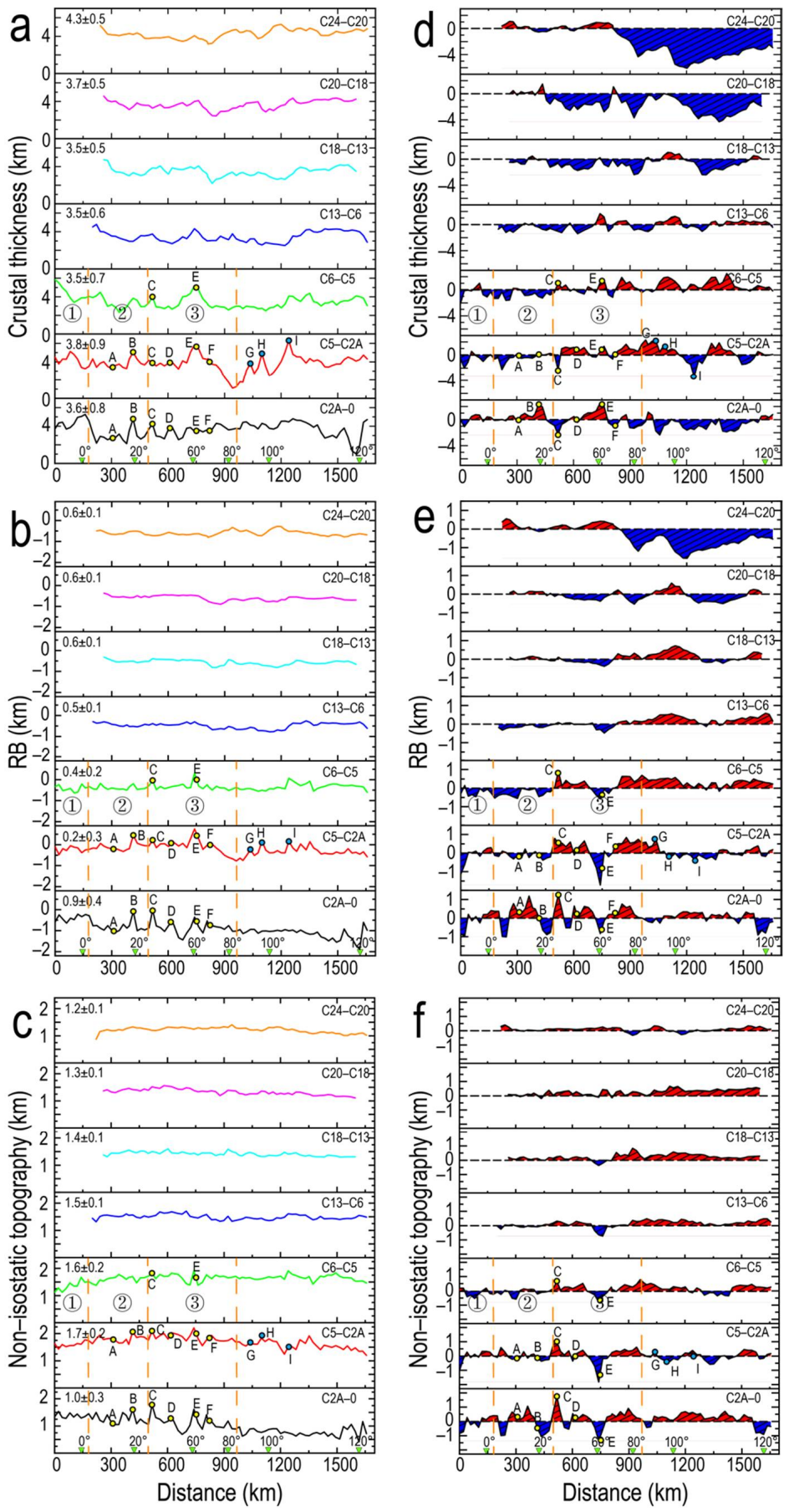

Figure 5. (a-c) indicate the variations of crustal thickness, residual bathymetry, and non-isostatic topography, respectively, along the Eurasian Basin opening axis at different stages of the basin evolution. (1) indicates the WVZ. (2) indicates the SMZ. (3) indicates the EVZ. The numbers in the upper left corner and upper right corner of the graph indicate mean \pm standard deviation and different stages of the basin' evolution, respectively. Yellow circles indicate the basement ridges. Cyan circles indicate the newly identified basement ridges. (d-f) indicate the asymmetry of crustal thickness, residual bathymetry, and non-isostatic topography, respectively, along the Eurasian Basin opening axis at different stages of the basin' evolution.

During C24-C20, the basin had a strong asymmetry to the east of $70^{\circ} \mathrm{E}$. The crust of the Nansen Basin was about $3.8 \mathrm{~km}$ thicker than that of the Amundsen Basin. Subsequently, the asymmetry of crustal thickness rapidly weakened. During C20-C13 (44-33 Ma), the 
crustal thickness asymmetry of the basin as a whole was still negative, but the amplitude decreased by about $1 / 2$. During C13-0, asymmetric polarity of the crustal thickness of the basin changed along the axis. It was characterized by a local high amplitude asymmetry anomaly. During C13-C2A, the asymmetry of the western part of the basin (west of $29^{\circ} \mathrm{E}$ ) was mainly negative, and the crust of the Nansen Basin was $0.5-0.6 \mathrm{~km}$ thicker than that of the Amundsen Basin. During C2A-0, the asymmetric polarity of crustal thickness reversed in the western part of the ocean basin, but the overall asymmetry was weak, with an average amplitude of $0.2 \mathrm{~km}$. The basement ridge had strong asymmetry. The asymmetry of basement ridge $C$ and $E$ were negative and positive, respectively, with the amplitude of $\sim 2 \mathrm{~km}$. During C5-C2A, the crust of the north side of basement ridge D was about $1 \mathrm{~km}$ thicker than that of the south side. During C6-C5, the asymmetry in the eastern part of the basin (east of $85^{\circ} \mathrm{E}$ ) was mainly positive, and the crust of the Amundsen Basin was about $0.7 \mathrm{~km}$ thicker than that of Nansen Basin. During C5-C2A, there were two asymmetric negative values with high amplitude $\left(108^{\circ} \mathrm{E}\right.$ and $\left.118^{\circ} \mathrm{E}\right)$ in the eastern part of the basin, and the maximum values were $3.3 \mathrm{~km}$ and $1.5 \mathrm{~km}$, respectively. During C2A-0, the asymmetric polarity of the eastern basin became negative, and the crust of the Nansen Basin was about $0.7 \mathrm{~km}$ thicker than that of the Amundsen Basin.

\subsection{Residual Bathymetry}

Except for C2A-0, the average residual bathymetry $(\mathrm{RB})$ of the Eurasian Basin ranged from $-0.6 \mathrm{~km}$ to $-0.2 \mathrm{~km}$. During the initial spreading stage (C24-C20), the average RB of the basin was $-0.58 \mathrm{~km}$. During C20-C18, the average RB of the basin decreased to $-0.6 \mathrm{~km}$ and then systematically increased. The RB reached the maximum value $(-0.2 \mathrm{~km})$ during C5-C2A. During C24-C13, the amplitude of RB variation was only $0.03 \mathrm{~km}$, and the spatial variability was relatively weak $(S T D=0.11 \mathrm{~km})$. During C13-C6, RB increased from $-0.57 \mathrm{~km}$ to $-0.48 \mathrm{~km}$. Subsequently, the RB rapidly increased, and the amplitude of $\mathrm{RB}$ variation reached up to $\sim 0.15 \mathrm{~km}$. In addition, the spatial variability of the RB became strong, and the basin showed some locally high RB values, most of which were located at the basement ridges. During C2A-0, due to the existence of the central valley, the average $\mathrm{RB}$ of the basin was as low as $-0.91 \mathrm{~km}$ and gradually decreased from west to east. In addition, the basin had strong spatial variability $(\mathrm{STD}=0.35 \mathrm{~km})$, and the basement ridge along the axis had a high RB.

During C24-C20, the RB showed relative symmetry to the west of $70^{\circ} \mathrm{E}$, while the $\mathrm{RB}$ showed asymmetry to the east of $70^{\circ} \mathrm{E}$. The RB of the Nansen Basin was about $0.77 \mathrm{~km}$ higher than that of the Amundsen Basin to the east of $70^{\circ}$ E. Subsequently, the asymmetry of RB significantly weakened. During C20-C18, the RB asymmetry of the basin was mainly negative. During C18-C6, the RB asymmetry gradually became opposite to that at C24-C20. During C6-C5, the basin still showed a relatively high positive asymmetry to the east of $70^{\circ}$ E. During C5-0, asymmetric polarity of the RB alternated with positive and negative along the axis. The asymmetry of basement ridge $B$ and $E$ were opposite to that of the crustal thickness, showing positive and negative values, respectively, and an amplitude exceeding $1 \mathrm{~km}$.

\subsection{Non-Isostatic Topography}

A large number of observations and simulations showed that the ridge axis is in an isostatic state, so the basin had the lowest non-isostatic topography $(1 \mathrm{~km})$ during C2A-0 [24,31]. Compared to the RB, the non-isostatic topography had a greater variability. During C24-C2A, the non-isostatic topography gradually increased, and the variation amplitude reached $\sim 0.5 \mathrm{~km}$, indicating that the compensation for the topography was increasingly insufficient. During C24-C6, the spatial variability of non-isostatic topography of the basin was weak (STD $<0.1 \mathrm{~km}$ ), and the eastern and western parts of the basin had nearly the same non-isostatic topography values. During C6-0, the spatial variability of the non-isostatic topography of the basin gradually became strong and showed some locally high non-isostatic topography, most of which were located at the basement ridge. 
During C24-C20, the non-isostatic topography of the north and south sides of the basin had nearly the same values. During C20-C6, the asymmetry value of the non-isostatic topography of the basin was positive, except that the asymmetry value near $62^{\circ} \mathrm{E}$ was negative. In addition, the asymmetry amplitude gradually increased from west to east, indicating that the Amundsen Basin of the eastern basin was in a relatively non-isostatic state, and the lithosphere may have been supported by tectonic stress. During C6-0, asymmetric polarity of the non-isostatic topography alternated with positive and negative values along the axis. The asymmetry of basement ridges $\mathrm{B}$ and $\mathrm{E}$ were positive and negative, respectively, with amplitude even exceeding $1 \mathrm{~km}$. The WVZ had relatively weak asymmetry compared to that of the SMZ and the WVZ.

\section{Discussion}

Our results showed that the Eurasian Basin had an abnormally thin crust, low residual bathymetry, and non-isostatic lithosphere due to the fact that the Gakkel Ridge forming the Eurasian Basin is an ultra-slow spreading ridge. The spreading rate controls the mantle melting. When the spreading rate drops below $20 \mathrm{~mm} /$ year, conduction cooling limits the mantle melting, resulting in a melt decrease [4,32]. In addition, compared to the fast spreading ridge, the lithosphere of the ultra-slow spreading ridge is colder and harder. Thus, the crust cannot sink to a sufficient depth to compensate the topography after magma eruption, resulting in the non-isostatic topography [16,33]. It is generally believed that with a decrease in the spreading rate, the melting degree of the lower mantle will decrease, and the crust will become thin [2]. The spreading rate of the Eurasian Basin gradually decreases from west to east [11]. However, the crustal thickness of the eastern basin is nearly same as that of the western basin, and it is even thicker than that of the western basin, which indicates that the crustal thickness of the Eurasian Basin is not positively correlated with the spreading rate. The phenomenon has been observed in the ultra-slow spreading Mohns Ridge and Southwest Indian Ridge [24,34]. According to the temporal and spatial variations of crustal thickness, RB and non-isostatic topography, the spatial variability of crustal structure was relatively weak during C24-C13, and the crustal structure was characterized by regional variation. In contrast, during C13-0, the spatial variability of crustal structure of the basin gradually became strong and crustal structure was characterized by local variation. Next, we analyze and discuss the two stages of the tectonic-magmatic process of the Eurasian Basin.

\subsection{The Crustal Structure during C24-C13}

The Eurasian Basin had the thickest crust and lowest non-isostatic topography during C24-C20, indicating that the lithosphere was in a relatively hot and isostatic state. As shown in Figure 5, the Western Eurasian Basin has a thicker crustal thickness and higher RB than the Eastern Eurasian Basin, except for the eastern Nansen Basin at $97-113^{\circ}$ E. We speculate that this is due to the northward movement of Greenland. In the late Cretaceous ( 80 Ma), Greenland began to move northward, which led to the north of Greenland gradually change from the extensional state to the compressive state. The compression between Greenland and Ellesmere Islands reached the peak in the middle Eocene ( 49 MA), resulting in the so called "Eurekan" deformation $[35,36]$. It has been proposed that the northward movement of Greenland may have led to the formation of the Lomonosov Ridge Platform and stimulated the volcanic eruptions that formed high-amplitude magnetic anomalies at the present-day Morris Jessup Rise and Yermak Plateau [10,11,37]. We suggest that Greenland served as an obtuse that intruded into the Lincoln Sea and forced the mantle of the Lincoln Sea to flow westward into the Eurasian Basin, which caused the enhancement of mantle melting and magmatism. Compression and magmatism thickened the crust of the western part of the basin and uplifted the terrain.

During C24-C20, the crustal structure of the eastern part of the basin had abnormally strong asymmetry. The crustal thickness asymmetry with long wavelength and high amplitude is generally considered to be related with hot spots or large-scale magmatism [38]. 
Hot spots will thicken the crust near a hot spot, forming a regional asymmetric crustal structure $[24,26,39,40]$. According to analysis of magnetic anomaly data and seismic data, it was found that the Kara Sea Shelf in the south of the eastern Eurasian Basin (Figure 3) has high amplitude positive magnetic anomaly $(>150 \mathrm{nT})$ and low velocity anomaly [41,42]. We speculate that there may be mantle upwelling beneath the Kara Sea Shelf in the south of the Eastern Eurasian Basin, which provides a large amount of melt for the crustal accretion of the southern part of the Eastern Eurasian Basin. Unexpectedly, the northern side of the Eastern Eurasian Basin has a faster spreading rate than the southern side [11]. It is easier to develop large normal faults or detachment faults in slow and ultra-slow spreading ridges with little magma [43,44]. The magma supply of the northern side of the Eastern Eurasian Basin is lesser and the crustal accretion should be dominated by tectonic extension. The tectonic extension can accommodate more lithospheric spreading, so the flank where large faults are developed often corresponds to a faster spreading rate [30]. In addition, ridges are prone to move to the weaker and hotter side of the lithosphere [38]. Strong magmatic activity makes the lithosphere of the southern side of the Eastern Eurasian Basin hotter than that of the northern side. This may cause the ridge jump to the south, resulting in a faster spreading rate in the north. During $\mathrm{C} 20-\mathrm{C} 13$, the non-isostatic topography of the northern side of the Eurasian Basin was higher than that of the southern side, indicating that the lithosphere of the northern side of the basin is supported by tectonic stress. Magmatic activities were found to be mostly concentrated on the southern side of the Eurasian Basin, while the northern side is mainly tectonic extension. In the ultra-slow spreading ridge, large normal faults can be active for a long time. The continuous extension and uplift of the footwall cause crustal thinning and topographic uplift, which deviate from the Airy compensation model [45], thus forming a non-isostatic topography.

\subsection{The Crustal Structure during C13-0}

During C13-0, the RB and average crustal thickness of the Eurasian Basin significantly increased. Compared to the previous spreading process, the spatial variability of the crustal structure of the Eurasian Basin was enhanced. In addition, a large number of off-axis linear basement ridges appeared along the ridge axis. Unexpected, an abnormally thick crust $(>7 \mathrm{~km})$ appears in some areas of the Eurasian Basin, indicating that the local magmatic activity of the ultra-slow spreading ridge is not weak and may even be equivalent to that of the fast-spreading ridges. The spreading rate is not the only factor controlling the thermal structure and crustal thickness of the lithosphere, and the mantle thermochemical anomaly and magma supply intensity also are crucial factors [34,46,47]. The accretion of oceanic lithosphere is episodic for ridges with various spreading rates, but the frequency of these episodes is the lowest for slow spreading ridges [30]. During the magma enhancement period, more melt and higher magma supply frequency form a thicker crust. In the ultraslow spreading ridge, the melt flows along the lithosphere-asthenosphere boundary to the volcanic center [1,4]. We suggest that the melt focusing supply mode could provide more melt for the volcanic center, thus forming the thicker crustal thickness during magmatic enhancement period.

In the ultra-slow spreading ridge, the serpentinization and fluid circulation could reach $15 \mathrm{~km}$ depth, which enhances the stability of the lithosphere-asthenosphere boundary so that the basement ridge can stably exist for a long time [4]. We identified three relatively obvious basement ridges in the eastern part of the basin based on the analysis of crustal structure (G, H, I in Figure 5). Our results showed that the crustal structure of basement ridges $C$ and $E$ have obvious asymmetry. According to the formation mechanism of the "Inner Corner" high topography of the transform fault system, Ling et al. [16] attributed the high asymmetry of basement ridges $\mathrm{C}$ and $\mathrm{E}$ to the concentration of tectonism on one flank of the Gakkel Ridge. During C6-0, the western part of the basin had stronger spatial variability and more frequent asymmetric polarity reversal than the eastern part of the basin. It has been proposed that the separation of Greenland and Svalbard at magnetic isochron C5/C6 led to hotter and less viscous North Atlantic mantle inflows into the 
Eurasian Basin $[4,46,48,49]$. This not only establishes a stable melt supply source in the WVZ but also promotes the focusing volcanism of the SMZ and the EVZ, resulting in prominent locally crustal structure characteristics and stronger spatial variability of crustal structure in the western part of the basin. Although the melt eventually focused on the ridge axis at the shallow levels, the advection of heat in the mantle and heat introduced by fractional crystallization could preferentially occur beneath one ridge flank, resulting in asymmetry in the magma distribution and tectonic extension [30]. Therefore, we suggest that the mantle upwelling is unlikely to be perfectly centered beneath the ridge axis but may randomly occur on one side of the ridge, resulting in asymmetric polarity reversal.

\section{Conclusions}

Using the latest bathymetry, gravity anomaly, crustal age, and sediment thickness data, we calculated the crustal thickness, residual bathymetry, and non-isostatic topography of the Eurasian Basin. By analyzing their temporal and spatial variations, we studied the tectonic-magmatic history, crustal structure, and crustal accretion mode of the Eurasian Basin. Our main conclusions are as follows:

1. The tectonic-magmatic process of the Eurasian Basin can be divided into two stages During C24-C13, the crustal structure of the basin was characterized by regional variations, while the crustal structure of the basin was characterized by local variations during C13-0.

2. During C24-C13, the western part of the basin had a thicker crust and higher RB than the eastern part of the basin. The northward movement of Greenland compressed the western part of the Eurasian Basin to a certain extent and forced the mantle of the Lincoln Sea to flow westward into the Eurasian basin, resulting in crustal thickening and topographic uplift.

3. During C24-C20, the crustal structure of the eastern part of the basin showed asymmetry. We speculate that there may be mantle upwelling beneath the Kara Sea Shelf in the south of the Eastern Eurasian Basin, which provides a large amount of melt for the crustal accretion of the southern part of the Eastern Eurasian Basin. The tectonic extension on the northern side of the eastern part of the basin and the ridge jump to the south led to a faster spreading rate in the northern side of the eastern basin.

4. During C13-0, an abnormally thick crust $(>7 \mathrm{~km})$ appeared in some areas of the Eurasian Basin, indicating that the local magmatic activity of the ultra-slow spreading ridge is not weak and may even be equivalent to that of the fast spreading ridges. We attribute this to the melt-focusing supply.

5. During C6-0, the western part of the basin had stronger spatial variability and more frequent asymmetric polarity reversal than the eastern part of the basin. The inflow of North Atlantic mantle has led to the western part of the basin having prominent locally crustal structure characteristics. The mantle upwelling is unlikely to be perfectly centered beneath the ridge axis but may randomly occur on one side of the ridge, resulting in frequent asymmetric polarity reversal.

Author Contributions: Conceptualization, L.Z., Z.L. and T.Z.; data curation, L.Z., Z.L. and T.Z.; formal analysis, L.Z., T.Z., Z.L., M.L., P.Z., R.D. and C.L.; funding acquisition, L.Z. and T.Z.; investigation, L.Z., Z.L., T.Z., M.L. and P.Z.; methodology, L.Z., Z.L. and T.Z.; project administration, L.Z. and T.Z.; resources L.Z., Z.L. and T.Z.; software, L.Z. and Z.L.; supervision, L.Z. and T.Z.; validation, Z.L., M.L., P.Z., R.D. and C.L.; visualization, L.Z. and T.Z.; writing-original draft, L.Z. and Z.L.; writing-review and editing, L.Z., T.Z., Z.L., M.L., P.Z., R.D. and C.L. All authors have read and agreed to the published version of the manuscript.

Funding: This research was funded by the National Natural Science Foundation of China (grant nos. 41976079, 41676039 and 41930535) and Shandong Young Teacher Growth Program.

Institutional Review Board Statement: Not applicable.

Informed Consent Statement: Not applicable. 
Data Availability Statement: IBCAO Ver. 4.0: the data that support the findings of this study are openly available from https:/ / www.gebco.net/about_us/committees_and_groups/scrum/ibcao/ ibcao_v4.html, accessed on 1 November 2021; DTU21 gravity model: The data that support the findings of this study are provided by O. B. Andersen, accessed on 1 November 2021; ArcCRUST sediment data: The data that support the findings of this study are openly available from http: / / earthdynamics.org/data/, accessed on 1 November 2021; Crustal age data: The data that support the findings of this study are openly available from https:/ / earthbyte.org/webdav/ftp/earthbyte/ agegrid/2020/, accessed on 1 November 2021.

Acknowledgments: We are grateful to O. B. Andersen for providing DTU21 gravity data.

Conflicts of Interest: The authors declare no conflict of interest.

\section{References}

1. Jokat, W.; Ritzmann, O.; Schmidt-Aursch, M.C.; Drachev, S.; Gauger, S.; Snow, J. Geophysical evidence for reduced melt production on the Arctic ultraslow Gakkel midocean ridge. Nature 2003, 423, 962-965. [CrossRef]

2. $\quad$ Michael, P.J.; Langmuir, C.H.; Dick, H.J.B.; Snow, J.E.; Goldstein, S.L.; Graham, D.W.; Lehnert, K.; Kurras, G.; Jokat, W.; Mühe, R.; et al. Magmatic and amagmatic seafloor generation at the ultraslow-spreading Gakkel ridge, Arctic Ocean. Nature 2003, 423, 956-961. [CrossRef]

3. Schmidt-Aursch, M.C.; Jokat, W. 3D gravity modelling reveals off-axis crustal thickness variations along the western Gakkel Ridge (Arctic Ocean). Tectonophysics 2016, 691, 85-87. [CrossRef]

4. Schlindwein, V.; Schmid, F. Mid-ocean-ridge seismicity reveals extreme types of ocean lithosphere. Nature 2016, 535, 276-279. [CrossRef]

5. Jokat, W.; Schmidt-Aursch, M.C. Geophysical characteristics of the ultraslow spreading Gakkel Ridge, Arctic Ocean. Geophys. J. Int. 2007, 168, 983-998. [CrossRef]

6. Urlaub, M.; Schmidt-Aursch, M.C.; Jokat, W.; Kaul, N. Gravity crustal models and heat flow measurements for the Eurasia Basin, Arctic Ocean. Mar. Geophys. Res. 2009, 30, 277-292. [CrossRef]

7. Alvey, A.; Gaina, C.; Kusenir, N.J.; Torsvik, T.H. Intergrated crustal thickness mapping and plate reconstructions for the high Arctic. Earth Planet. Sci. Lett. 2008, 274, 310-321. [CrossRef]

8. Petrov, O.; Morozov, A.; Shokalsky, S.; Kashubin, S.; Artemieva, I.M.; Sobolev, N.; Petrov, E.; Ernst, R.E.; Sergeev, S.; Smelror, M. Crustal structure and tectonic model of the Arctic region. Earth Sci. Rev. 2015, 154, 29-71. [CrossRef]

9. Lebedeva-Ivanova, N.; Gaina, C.; Minakov, A.; Kashubin, S. ArcCRUST: Arctic Crustal Thickness From 3-D Gravity Inversion. Geochem. Geophys. Geosystems 2019, 20, 3225-3247. [CrossRef]

10. Brozena, J.M.; Childers, V.A.; Lawver, L.A.; Gahagan, L.M.; Forsberg, R.; Faleide, J.I.; Eldholm, O. New aerogeophysical study of the Eurasia Basin and Lomonosov Ridge: Implications for basin development. Geology 2003, 31, 825-828. [CrossRef]

11. Glebovsky, V.Y.; Kaminsky, V.D.; Minakov, A.N.; Merkur'ev, S.A.; Childers, V.A.; Brozena, J.M. Formation of the Eurasia Basin in the Arctic Ocean as inferred from geohistorical analysis of the anomalous magnetic field. Geotectonics 2006, 40, 263-281. [CrossRef]

12. Cochran, J.R.; Kurras, G.J.; Edwards, M.H.; Coakley, B.J. The Gakkel Ridge: Bathymetry, gravity anomalies, and crustal accretion at extremely slow spreading rates. J. Geophys. Res. Solid Earth 2003, 108, 2116. [CrossRef]

13. Jokat, W.; Micksch, U. Sedimentary structure of the Nansen and Amundsen basins, Arctic Ocean. Geophys. Res. Lett. 2004, 32, L02603. [CrossRef]

14. Nikishin, A.M.; Gaina, C.; Petrov, E.I.; Malyshev, N.A.; Freiman, S.I. Eurasia Basin and Gakkel Ridge, Arctic Ocean: Crustal asymmetry, ultra-slow spreading and continental rifting revealed by new seismic data. Tectonophysics 2017, 746, 64-82. [CrossRef]

15. Vogt, P.R.; Taylor, P.T.; Kovacs, L.C.; Johnson, G.L. Detailed aeromagnetic investigation of the Arctic Basin. J. Geophys. Res. Solid Earth 1981, 86, 6323-6333. [CrossRef]

16. Ling, Z.L.; Gao, J.Y.; Zhao, L.H.; Yang, C.G.; Guan, Q.S.; Zhang, T. The asymmetric crustal structure of basement ridges of the Gakkel Ridge. Chin. J. Geophys. 2019, 62, 1755-1771. (In Chinese) [CrossRef]

17. Jakobsson, M.; Mayer, L.A.; Bringensparr, C.; Castro, C.F.; Mohammad, R.; Johnson, P.; Ketter, T.; Accettella, D.; Amblas, D.; An, L.; et al. The International Bathymetric Chart of the Arctic Ocean Version 4.0. Sci. Data 2020, 7, 176. [CrossRef]

18. Andersen, O.B.; Knudsen, P. The DTU17 Global Marine Gravity Field: First Validation Results. In Fiducial Reference Measurements for Altimetry; Mertikas, S., Pail, R., Eds.; Springer: Berlin/Heidelberg, Germany, 2019; Volume 150, pp. 83-87; ISBN 978-3-03039437-0.

19. Seton, M.; Müller, R.D.; Zahirovic, S.; Williams, S.; Wright, N.M.; Cannon, J.; Whittaker, J.; Matthews, K.J.; McGirr, R. A global dataset of present-day oceanic crustal age and seafloor spreading parameters. Geochem. Geophys. Geosystems 2020, 21, e2020GC009214. [CrossRef]

20. Müller, R.D.; Zahirovic, S.; Williams, S.E.; Cannon, J.; Seton, M.; Bower, D.J.; Tetley, M.G.; Heine, C.; Breton, E.L.; Liu, S.; et al. A global plate model including lithospheric deformation along major rifts and orogens since the Triassic. Tectonics 2019, 38, 1884-1907. [CrossRef]

21. Fullea, J.; Fernàndez, M.; Zeyen, H. FA2BOUG-A FORTRAN 90 code to compute Bouguer gravity anomalies fron gridded free-air anomalies: Application to the Atlantic-Mediterranean transition zone. Comput. Geosci. 2008, 34, 1665-1681. [CrossRef] 
22. Rao, D.B.; Babu, N.R. A FORTRAN-77 computer program for three-dimensional analysis of gravity anomalies with variable density contrast. Comput. Geosci. 1991, 17, 655-667. [CrossRef]

23. Turcotte, D.L.; Schubert, G. Geodynamics, 2nd ed.; Cambridge University Press: Cambridge, UK, $2002 ;$ p. 472.

24. Zhang, T.; Gao, J.Y.; Wang, W.; Wu, Z.C.; Shen, Z.Y.; Yang, C.G. Asymmetric spreading rates and crustal structures of the Mohns Ridge since 20 Ma. Chin. J. Geophys. 2018, 61, 3263-3277. (In Chinese) [CrossRef]

25. Parker, R.L. The rapid calculation of potential anomalies. Geophys. J. R. Astron. Soc. 1973, 31, 447-455. [CrossRef]

26. Wang, T.; Lin, J.; Tucholke, B.; Chen, Y. Crustal thickness anomalies in the North Atlantic Ocean basin from gravity analysis. Geochem. Geophys. Geosystems 2011, 12, Q0AE02. [CrossRef]

27. Stein, C.A.; Stein, S. A model for the global variation in oceanic depth and heat flow with lithospheric age. Nature 1992, 359, 123-129. [CrossRef]

28. Tucholke, B.E.; Lin, J. A geological model for the structure of ridge segments in slow-spreading ocean crust. J. Geophys. Res. Solid Earth 1994, 99, 11937-11958. [CrossRef]

29. Cannat, M.; Sauter, D.; Mendel, V.; Ruellan, E.; Okino, K.; Escartin, J.; Combier, V.; Baala, M. Modes of seafloor generation at a melt-poor ultraslow-spreading ridge. Geology 2006, 34, 605-608. [CrossRef]

30. Wang, T.; Tucholke, B.E.; Lin, J. Spatial and temporal variations in crustal production at the Mid-Atlantic Ridge, $25^{\circ} \mathrm{N}-27^{\circ} 30^{\prime}$ and 0-27 Ma. J. Geophys. Res.: Solid Earth 2015, 120, 2119-2142. [CrossRef]

31. Olive, J.A.; Behn, M.D.; Ito, G.; Buck, W.R.; Escartin, J.; Howell, S. Sensitivity of seafloor bathymetry to climate-driven fluctuations in mid-ocean ridge magma supply. Science 2015, 350, 310-313. [CrossRef]

32. Dick, H.J.B.; Lin, J.; Schouten, H. An ultraslow-spreading class of ocean ridge. Nature 2003, 426, 405-412. [CrossRef]

33. Cannat, M.; Rommevaux-Jestin, C.; Sauter, D.; Deplus, C.; Mendel, V. Formation of the axial relief at the very slow spreading Southwest Indian Ridge ( $49^{\circ}$ to $69^{\circ}$ E). J. Geophys. Res. Solid Earth 1999, 104, 22825-22843. [CrossRef]

34. Chen, J.; Cannat, M.; Tao, C.; Sauter, D.; Munschy, M. 780 Thousant Years of Upper-Crustal Construction at a Melt-Rich Segment of the Ultraslow Spreading Southwest Indian Ridge 50²8'․ J. Geophys. Res. Solid Earth 2021, 126, e2021JB022152. [CrossRef]

35. Tegner, C.; Storey, M.; Holm, P.M.; Thorarinsson, S.B.; Zhao, X.; Lo, C.H.; Knudsen, M.F. Magmatism and Eurekan deformation in the High Arctic Large Igneous Province: Ar-40-(39) age of Kap Washington Group volcanics, North Greenland. Earth Planet. Sci. Lett. 2011, 303, 203-214. [CrossRef]

36. Gaina, C.; Nikishin, A.M.; Petrov, E.I. Ultraslow spreading, ridge relocation and compressional events in the East Arctic region: A link to the Eurekan orogeny? Arktos 2015, 1, 16. [CrossRef]

37. Døssing, A.; Jackson, H.R.; Matzka, J.; Einarsson, I.; Rasmussen, T.M.; Olesen, A.V.; Brozena, J.M. On the origin of the Amerasia Basin and the High Arctic Large Igneous Province-Results of new aeromagnetic data. Earth Planet. Sci. Lett. 2013, 363, 219-230. [CrossRef]

38. Müller, R.D.; Roest, W.R.; Roter, J.Y. Asymmetric sea-floor spreading caused by ridge-plume interactions. Nature 1998, 396, 455-459. [CrossRef]

39. Ito, G.; Lin, J.; Graham, D. Observational and theoretical studies of the dynamics of mantle plume-mid-ocean ridge interaction. Rev. Geophys. 2003, 41, 1017. [CrossRef]

40. Dyment, J.; Lin, J.; Baker, E.T. Ridge-hotspot interactions: What mid-ocean ridges tell us about Earth processes. Oceanography 2007, 20, 102-115. [CrossRef]

41. Koulakov, I.Y.; Gaina, C.; Dobretsov, N.L.; Vasilevsky, A.N.; Bushenkova, N.A. Plate reconstructions in the Arctic region based on joint analysis of gravity, magnetic, and seismic anomalies. Russ. Geol. Geophys. 2013, 54, 859-873. [CrossRef]

42. Jakovlev, A.V.; Bushenkova, N.A.; Koulakov, I.Y.; Dobretsov, N.L. Structure of the upper mantle in the Circum-Arctic region from regional seismic tomography. Russ. Geol. Geophys. 2012, 53, 963-971. [CrossRef]

43. Escartin, J.; Smith, D.K.; Cann, J.R.; Schouten, H.; Escrig, S. Central role of detachment faults in accretion of slow-spreading oceanic lithosphere. Nature 2008, 455, 790-794. [CrossRef]

44. Tucholke, B.E.; Behn, M.D.; Buck, W.R.; Lin, J. Role of melt supply in oceanic detachment faulting and formation of megamullions. Geology 2008, 36, 455-458. [CrossRef]

45. Buck, W.R. Flexural rotation of normal faults. Tectonics 1988, 7, 959-973. [CrossRef]

46. Zhang, T.; Gao, J.Y.; Chen, M.; Yang, C.G.; Shen, Z.Y.; Zhou, Z.Y.; Wu, Z.C.; Sun, Y.F. Mantle melting factors and amagmatic crustal accretion of the Gakkel ridge, Arctic Ocean. Acta Oceanol. Sin. 2015, 34, 42-48. [CrossRef]

47. O'Connor, J.M.; Jokat, W.; Michael, P.; Schmidt-Aursch, M.C.; Miggins, D.P.; Koppers, A.A.P. Thermochemical anomalies in the upper mantle control Gakkel Ridge accretion. Nat. Commun. 2021, 12, 6962. [CrossRef]

48. Goldstein, S.L.; Soffer, G.; Langmuir, C.H.; Lehnert, K.A.; Graham, D.W.; Michael, P.J. 2008. Origin of a 'Southern Hemisphere' geochemical signature in the Arctic upper mantle. Nature 2008, 453, 89-93. [CrossRef]

49. Sauter, D.; Sloan, H.; Cannat, M.; Goff, J.; Patriat, P.; Schaming, M.; Roest, W.R. From slow to ultra-slow: How does spreading rate affect seafloor roughness and crustal thickness? Geology 2011, 39, 911-914. [CrossRef] 